\title{
Basic density and pulp yield relationship with some chemical parameters in eucalyptus trees
}

\author{
Ana Maria Loureiro da Seca ${ }^{(1)}$ e Fernando Manoel de Jesus Domingues ${ }^{(1)}$
}

(1)Universidade de Aveiro, Dep. de Química, 3810-193 Aveiro, Portugal. E-mail: anaseca@notes.uac.pt, fdomingues@dq.ua.pt

\begin{abstract}
The objective of this work was to evaluate the use of basic density and pulp yield correlations with some chemical parameters, in order to differentiate an homogeneous eucalyptus tree population, in terms of its potential for pulp production or some other technological applications. Basic density and kraft pulp yield were determined for 120 Eucalyptus globulus trees, and the values were plotted as frequency distributions. Homogenized samples from the first and fourth density quartiles and first and fourth yield quartiles were submitted to total phenols, total sugars and methoxyl group analysis. Syringyl/guaiacyl (S/G) and syringaldehyde/vanillin $(\mathrm{S} / \mathrm{V})$ ratios were determined on the kraft lignins from wood of the same quartiles. The results show the similarity between samples from high density and low yield quartiles, both with lower S/G (3.88-4.12) and S/V (3.99-4.09)

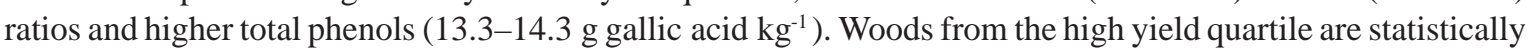
distinguished from all the others because of their higher S/G (5.15) and S/V (4.98) ratios and lower total phenols (8.7 $\mathrm{g}$ gallic acid $\mathrm{kg}^{-1}$ ). Methoxyl group and total sugars parameters are more adequate to distinguish wood samples with lower density.
\end{abstract}

Index terms: Eucalyptus globulus, syringyl, guaiacyl, phenols, methoxyl group, kraft pulping.

\section{Densidade e rendimento em polpa celulósica e sua relação com alguns parâmetros químicos no eucalipto}

\begin{abstract}
Resumo - O objetivo deste trabalho foi avaliar a aplicabilidade de correlações entre rendimento em polpa e densidade básica com alguns parâmetros químicos, para diferenciar uma população homogênea de árvores de eucalipto, em termos de capacidade de produção de polpa celulósica ou de outras aplicações. Determinou-se a densidade básica e o rendimento em polpa celulósica em 120 árvores de Eucalyptus globulus, e os resultados foram representados como distribuição de freqüências. Na madeira das árvores dos primeiro e quarto quartis de densidade e de rendimento, determinaram-se os teores de fenóis totais, açúcares totais e grupos metoxílicos. Nas respectivas ligninas kraft determinaram-se as razões seringilo/guaiacilo (S/G) e seringaldeído/vanilina (S/V). As amostras dos quartis de alta densidade e as de baixo rendimento foram semelhantes, ambas com baixos valores de S/V (3,99-4,09) e S/G (3,88-4,12) e os mais elevados teores de fenóis totais (13,3-14,3 g de ácido gálico por quilograma). As madeiras do quarto quartil de rendimento são estatisticamente distintas das outras, com as maiores razões $\mathrm{S} / \mathrm{G}(5,15)$ e S/V $(4,98)$ e os menores teores de fenóis totais (8,7 g de ácido gálico por quilograma). Os parâmetros grupos metoxílicos e açúcares totais são os mais adequados para a diferenciação das amostras provenientes do primeiro quartil de densidade.
\end{abstract}

Termos para indexação: Eucalyptus globulus, seringilo, guaiacilo, fenóis, grupos metoxílicos, cozimento kraft.

\section{Introduction}

Due to the natural variability of Eucalyptus globulus, several parameters can be used to evaluate the wood potential for pulp, paper or wood industries. Included here are pulp yield, correlated with delignification, and basic density, one of the most important selection criteria in breeding programs for pulping (Miranda et al., 2001), and an excellent indicator of the principal physical and mechanical properties of wood (Ona et al., 1997).

Several chemical parameters with some correlation with delignification and wood processing can be used to select the best trees. The syringyl/guaiacyl ratio $(\mathrm{S} / \mathrm{G})$ is one of them, and can be determined successfully by analytical pyrolysis (del Río et al., 2005) or thioacidolysis (Evtuguin et al., 2001). However, these are expensive 
methods, only accessible to a few forest or industry research laboratories. Nevertheless the S/G resulting from the nitrobenzene oxidation of wood or isolated lignin (Chen, 1992) was shown to correlate very well with the pulping efficiency (Stewart et al., 2006). As expected, methoxyl group content affects the 3D structure of lignin, with implications both on the delignification process (Stewart et al., 2006) and wood flexibility (Abreu et al., 1999). Phenolic compounds seem also to be related to mechanical or chemical inhibition problems in pulping process (Conde et al., 1995). A low within-tree correlation of basic density to S/G ratio was found by Ona (Ona et al., 1998). Total sugars, total phenols and methoxyl group content don't have a direct and wellestablished relationship with wood density.

Some of the published work evaluating the relationship between $\mathrm{S} / \mathrm{G}$ ratio and pulp yield is based on reduced populations of trees from different origins and growth conditions (Wallis et al., 1996; Gonzalez-Vila et al., 1999; Rodrigues et al., 1999; del Río et al., 2005). No study has been yet published on the differentiation of wood samples from the same geographic area (with small density or yield differences values), based on lignin monomeric composition, total phenols, methoxyl group or total sugars content.

The aim of this work was to evaluate the use of basic density and pulp yield correlations with some chemical parameters, in order to differentiate an homogeneous eucalyptus tree population in terms of its potential for pulp production or some other technological applications.

\section{Material and Methods}

One hundred and twenty Eucalyptus globulus trees, seven years old, were randomly harvested (simple random sampling procedure), in a restrict geographic area, in Casa Nova da Galé, Portugal. Basic density (Technical Association of the Pulp and Paper Industry, 2002) and kraft pulp yield (sulfidity $25 \% \mathrm{Na}_{2} \mathrm{O}$; active alkali/wood weight $=0.180$; maximum temperature $160^{\circ} \mathrm{C}$; time to maximum temperature 2 hours; time at maximum temperature 1 hour) were determined for each individual, and plotted against their frequency.

Both basic density and pulp yield frequency distributions were sectioned into four quartiles (with 30 individuals each). Trees from the first and fourth density quartiles (trees with lower and higher basic density values), and from the first and fourth pulp yield quartiles (trees with lower and higher pulp yield values), were combined and submitted to chemical analysis.

Total phenols were determined by Folin-Ciocalteau spectrophotometric method (Cadahía et al., 1997). Methoxyl group was determined by a standard procedure TAPPI 209 su-72 (Technical Association of the Pulp and Paper Industry, 1972). For total sugars determination wood was subjected to treatment with $72 \% \mathrm{H}_{2} \mathrm{SO}_{4}$, at $20^{\circ} \mathrm{C}$ for 3 hours, followed by 1 hour and $30 \mathrm{~min}$ hydrolysis with $1 \mathrm{M} \mathrm{H}_{2} \mathrm{SO}_{4}$, at $100^{\circ} \mathrm{C}$ (Seaman hydrolysis). The released neutral monosaccharides were determined as alditol acetate derivatives by gas chromatography, after neutralization of $1 \mathrm{~mL}$ of solution with $\mathrm{NH}_{3}(200 \mu \mathrm{L}, 25 \%)$, reduction with $\mathrm{NaBH}_{4}(100 \mu \mathrm{L}$ solution $150 \mathrm{mg} \mathrm{mL}^{-1} \mathrm{NaBH}_{4}$ in $\mathrm{NH}_{3} 3 \mathrm{M}, 1$ hour, at $30^{\circ} \mathrm{C}$ ), and acetilation $(0.3 \mathrm{~mL}$ reaction mixture plus $0.1 \mathrm{~mL}$ of acetic acid, $0.45 \mathrm{~mL}$ of 1-methyl-imidazol, $3 \mathrm{~mL}$ of acetic anhydride), according to Coimbra et al. (1994).

The quantitative analysis was carried out on a GC Varian 3350, equipped with a flame ionization detector (FID) and with a DB-225 J\&W column (30 mx0.25 mm i.d. x $0.15 \mu \mathrm{m}$ film thickness). The chromatographic conditions were as follows: initial temperature, $220^{\circ} \mathrm{C}$ ( $5 \mathrm{~min}$ ); temperature rate $2^{\circ} \mathrm{C}$ per min; final temperature $230^{\circ} \mathrm{C}$ (5 min); injector temperature, $230^{\circ} \mathrm{C}$; detector temperature, $230^{\circ} \mathrm{C}$. The quantification was made using calibration curves with standards. Uronic acids were determined colorimetrically with $m$-phenylphenol (Coimbra et al., 1994).

Samples from each quartile were submitted to kraft cooking in the conditions described above. Lignins from the black liquors were isolated and submitted to nitrobenzene oxidation, according to Lawther et al. (1995). Product quantification was performed by HPLC using a $\mathrm{C}_{18}$ column and eluting with acetonitrile/water $(1: 8 \mathrm{v} / \mathrm{v})$ with $1 \%$ acetic acid. The $\mathrm{S} / \mathrm{V}$ ratio was defined as quotient of syringaldehyde and vanillin concentrations. The syringyl/guaiacyl ratio (S/G) was defined as quotient of the sum of syringaldehyde plus syringic acid concentrations and the sum of vanillin plus vanillic acid concentrations.

Statistical analysis was performed using LEASP (Bacelar-Nicolau et al., 1998) running on a personal computer. For principal component analysis (PCA) the normalized data matrix (Malinowski, 2002) was used, and for cluster analysis Euclidean distances (Johnson \& Wichern, 2002) were considered. All the statistical analysis was performed to a $95 \%$ confidence degree. 


\section{Results and Discussion}

The lower and higher limits of the first and fourth quartiles of pulp yield were $52.4-52.6 \%$ and $54.8-56.7 \%$, respectively. Basic density distribution in both quartiles was quite symmetric, with values from 0.500 to $0.550 \mathrm{~g} \mathrm{~cm}^{-3}$ in the first quartile, and from 0.600 to 0.650 in the fourth quartile. The range of basic density variation observed is lower then the one reported by Miranda et al. (2001) for a population of E. globulus.

Similar conclusions apply to the variation of pulp yield from the first to the fourth quartile. Although smaller than the reported in the literature (Miranda \& Pereira, 2001), the 2.2-4.3 percent difference, of the present work, may have a considerable economic and environmental impact in any pulp mill.

Table 1 summarizes the results from the chemical analyses performed on wood (total phenols, total sugars and methoxyl group) and kraft lignins (S/V and S/G) from each quartile. A higher $S / V$ and $S / G$ ratios correspond to samples from the fourth yield quartile (higher pulp yield values) and is in agreement with Stewart et al. (2006). Woods with higher pulp yield values simultaneously exhibit the lowest total phenols content. This result supports the idea that phenolic compounds are involved in inhibition problems in pulping process (Conde et al., 1995). The total phenol content of all quartiles is similar to those of Cadahía et al. (1997).

Methoxyl group content in woods from the fourth quartile of density and the first quartile of yield were identical, and only slightly lower than the other quartiles. This means that methoxyl group content is not a sensitive parameter to distinguish wood samples with higher density and low yield pulp.

The first quartile of density, which includes woods with lower basic density, forms a distinct group with intermediate values of $\mathrm{S} / \mathrm{G}, \mathrm{S} / \mathrm{V}$ and total phenols, but is

Table 1. Values of chemical parameters on woods and on kraft lignins from first and fourth quartile of density and pulp yield.

\begin{tabular}{|c|c|c|c|c|}
\hline Parameter & $\begin{array}{c}1^{\text {st }} \text { quartile } \\
\text { density }\end{array}$ & $\begin{array}{c}4^{\text {th }} \text { quartile } \\
\text { density }\end{array}$ & $\begin{array}{l}1^{\text {st }} \text { quartile } \\
\text { pulp yield }\end{array}$ & $\begin{array}{l}4^{\text {th }} \text { quartile } \\
\text { pulp yield }\end{array}$ \\
\hline & \multicolumn{4}{|c|}{ Woods } \\
\hline Total sugars (\%) & 59.0 & 63.9 & 63.1 & 66.1 \\
\hline $\begin{array}{l}\text { Total phenols } \\
\left(\mathrm{g} \text { gallic acid } \mathrm{kg}^{-1} \text { ) }\right.\end{array}$ & 12.1 & 13.3 & 14.3 & 8.7 \\
\hline \multirow[t]{2}{*}{ Methoxyl group (\%) } & 5.9 & 5.4 & 5.4 & 5.8 \\
\hline & \multicolumn{4}{|c|}{ Kraft lignins } \\
\hline Syringaldehyde/vanillin & 4.57 & 3.99 & 4.09 & 4.98 \\
\hline Syringyl/guaiacyl & 4.61 & 3.88 & 4.12 & 5.15 \\
\hline
\end{tabular}

a more significant one, because of its lower values of total sugars and higher methoxyl group contents.

In order to ascertain whether these relationships and variations have any statistical significance, data from Table 1 was submitted to principal component analysis. The correlation matrix obtained shows that the first and second factors account for, respectively, 72.6 and 26.2\% of the total variation and are mainly associated with variables S/V, S/G and total phenols (first factor), and methoxyl group and total sugars (second factor). This means that $\mathrm{S} / \mathrm{V}, \mathrm{S} / \mathrm{G}$ and total phenols are highly correlated, and therefore give the same type of information, as far as sample differentiation is concerned. The third and fourth factors (1.16\% of total variation) may be considered meaningless for sample differentiation.

Graphical display of the samples from first and fourth quartiles of basic density and pulp yield, according to the first two factors, allows us to distinguish with statistical significance the woods from each one of the quartiles. Woods from the fourth quartile of density and first quartile of pulp yield are quite similar, according to the first and second factors. This means that the differences on parameters values don't have statistical significance. The S/G and S/V ratios and total phenols parameters are statistically different in woods from the fourth quartile of pulp yield, and can be used to distinguish woods with high pulp yield from the others. According to the second factor, woods with low density (first quartile of density) form a distinct group with lower values of total sugars and higher methoxyl group content.

The distinctions between woods from the different quartiles referred above are in perfect agreement to the dendrogram (Figure 1), obtained from cluster analysis of all the variables and from reducing of the correlated variables to their arithmetic mean.

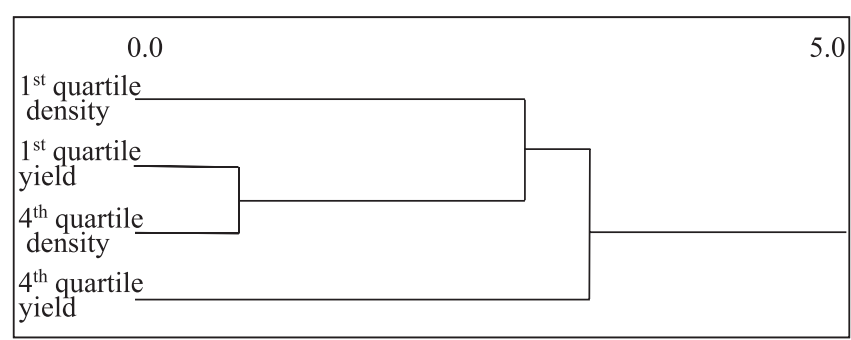

Figure 1. Dendrogram obtained from cluster analysis, representing the differentiation of the four samples. 
Nitrobenzene oxidation can be applied to the analysis of both wood and isolated lignin (Chen, 1992), although the $\mathrm{S} / \mathrm{G}$ in kraft lignin is slightly lower than in dioxan lignin (Pinto et al., 2002). Therefore, conclusions from the study based on kraft lignin could as well be obtained from direct oxidation of wood.

Since S/G and S/V ratios give the same information, as far as sample differentiation is concerned, it is suggested the use of $\mathrm{S} / \mathrm{V}$ ratio as a more suitable parameter for the routine evaluation of woods potential for pulp processing or other application.

\section{Conclusions}

1. Even in a homogeneous tree population, small variations of pulp yield and basic density can be predicted from the determination of some chemical parameters.

2. Woods with higher pulp yield have syringyl/guaiacyl (S/G), syringaldehyde/vanillin (S/V) and total phenols very distinct from woods with lower pulp yield, independently of the basic density values.

3. Woods with higher basic density and lower pulp yield are identical for $\mathrm{S} / \mathrm{V}, \mathrm{S} / \mathrm{G}$, methoxyl group and total sugars.

4. Methoxyl group and total sugars content are the best parameters to distinguish woods with lower density.

\section{Acknowledgements}

To Tecnocel - The Forest and Paper Research - and to PRODEP, for financial support.

\section{References}

ABREU, H.D.; NASCIMENTO, A.M.; MARIA, M.A. Lignin structure and wood properties. Wood Fiber Science, v.31, p.426-433, 1999.

BACELAR-NICOLAU, H.; NICOLAU, F.C.; DIAS, O.; RAMOS, L. LEASP97: an improvement in teaching and analyzing new methodology on probabilistic clustering models. In: INTERNATIONAL CONFERENCE ON TEACHING OF STATISTICS, 5., 1998, Singapore. Proceedings. Voorburg: International Statistical Institute, 1998. p.863-869.

CADAHÍA, E.; CONDE, E.; GARCÍA-VALLEJO, M.C.; FERNÁNDEZ DE SIMÓN, B. Tannin composition of Eucalyptus camaldulensis, E. globulus and E. rudis. Holzforschung, v.51, p.119-124, 1997.

CHEN, C.-L. Nitrobenzene and cupric oxide oxidations. In: LIN, S.Y.; DENCE, C.W. (Ed.). Methods in lignin chemistry. Berlin; New York: Springer-Verlag, 1992. p.301-319.
COIMBRA, M.A.; WALDRON, K.W.; SELVENDRAN, R.R. Isolation and characterization of cell wall polymers from olive pulp (Olea europaea L.). Carbohydrate Research, v.252, p.245-262, 1994.

CONDE, E.; CADAHÍA, E.; GARCÍA-VALLEJO, M.C.; FERNÁNDEZ DE SIMÓN, M.B. Polyphenolic composition of wood extracts from Eucalyptus camaldulensis, E. globulus and E. rudis. Holzforschung, v.49, p.411-417, 1995.

DEL RÍO, J.C.; GUTIÉRREZ, A.; HERNANDO, M.; LANDÍN, P.; ROMERO, J.; MARTÍNEZ, A.T. Determining the influence of eucalypt lignin composition in paper pulp yield using Py-GC/MS. Journal of Analytical and Applied Pyrolysis, v.74, p.110-115, 2005.

EVTUGUIN, D.V.; PASCOAL-NETO, C.; SILVA, A.M.S.; DOMINGUES, P.M.; AMADO, F.M.L.; ROBERT, D.; FAIX, O. Comprehensive study on the chemical structure of dioxane lignin from plantation Eucalyptus globulus wood. Journal of Agricultural and Food Chemistry, v.49, p.4252-4261, 2001.

GONZÁLEZ-VILA, F.J.; ALMENDROS, G.; DEL RÍO, J.C.; MARTÍN, F.; GUTIÉRREZ, A.; ROMERO, J. Ease of delignification assessment of wood from different Eucalyptus species by pyrolysis (TMAH)-GC/MS and CP/MAS C-13-NMR spectrometry. Journal of Analytical and Applied Pyrolysis, v.49, p.295-305, 1999.

JOHNSON, R.A.; WICHERN, D.W. Applied multivariate statistical analysis. 5 $^{\text {th }}$ ed. Upper Saddle River: Prentice Hall, 2002. 767p.

LAWTHER, J.M.; SUN, R.; BANKS, W.B. Extraction, fractionation, and characterization of structural polysaccharides from wheat straw. Journal of Agricultural and Food Chemistry, v.43, p.667-675, 1995.

MALINOWSKI, E.R. Factor analysis in chemistry. $3^{\text {rd }}$ ed. New York: Wiley, 2002. 372p.

MIRANDA, I.; ALMEIDA, M.H.; PEREIRA, H. Provenance and site variation of wood density in Eucalyptus globulus Labill at harvest age and its relation to a non-destructive early assessment. Forest Ecology and Management, v.149, p.235-240, 2001.

MIRANDA, I.; PEREIRA, H. Provenance effect on wood chemical composition and pulp yield for Eucalyptus globulus Labill. APPITA Journal, v.54, p.347-351, 2001.

ONA, T.; SONODA, T.; ITO, K.; SHIBATA, M. Relations between various extracted basic densities and wood chemical components in Eucalyptus globulus. Journal of Wood Science, v.44, p.165-168, 1998.

ONA, T.; SONODA, T.; ITO, K.; SHIBATA, M. Relationship between various extracted basic densities and wood chemical components in Eucalyptus camaldulensis. Wood Science and Technology, v.31, p.205-216, 1997.

PINTO, P.C.; EVTUGUIN, D.V.; PASCOAL-NETO, C.; SILVESTRE, A.J.D. Behaviour of Eucalyptus globulus lignin during kraft pulping. I. Analysis by chemical degradation methods. Journal of Wood Chemistry and Technology, v.22, p.93-108, 2002.

RODRIGUES, J.; MEIER, D.; FAIX, O.; PEREIRA, H. Determination of tree to tree variation in syringyl/guaiacyl ratio of Eucalyptus globulus wood lignin by analytical pyrolysis. Journal of Analytical and Applied Pyrolysis, v.48, p.121-128, 1999. 
STEWART, J.J.; KADLA, J.F.; MANSFIELD, S.D. The influence of lignin chemistry and ultrastructure on the pulping efficiency of clonal aspen (Populus tremuloides Michx.). Holzforschung, v.60, p.111-122, 2006.

TECHNICAL ASSOCIATION OF THE PULP AND PAPER INDUSTRY. Basic density and moisture content of pulpwood. Norcross, 2002. 8p. (TAPPI T 258 om-02).
TECHNICAL ASSOCIATION OF THE PULP AND PAPER INDUSTRY. Methoxyl content of pulp and wood. Atlanta, 1972. (TAPPI T 209 su-72).

WALLIS, A.F.A.; WEARNE, R.H.; WRIGHT, P.J. Analytical characteristics of plantation eucalypt woods relating to kraft pulp yields. Appita Journal, v.49, p.427-432, 1996.

Received on March 31, 2006 and accepted on September 5, 2006 